\title{
Continent formation through time
}

\author{
NICK M. W. ROBERTS ${ }^{1 *}$, MARTIN J. VAN KRANENDONK ${ }^{2}$, STEPHEN PARMAN ${ }^{3}$ \\ \& PETER D. CLIFT ${ }^{4}$ \\ ${ }^{1}$ NERC Isotope Geosciences Laboratory, British Geological Survey, Keyworth, \\ Nottingham NG12 5GG, UK \\ ${ }^{2}$ School of Biological, Earth and Environmental Sciences, and Australian Centre for \\ Astrobiology, University of New South Wales, Kensington, NSW 2052, Australia \\ ${ }^{3}$ Department of Earth, Environmental and Planetary Sciences, Brown University, \\ Providence, RI 02912, USA \\ ${ }^{4}$ Department of Geology and Geophysics, Louisiana State University, Baton Rouge, \\ LA 70803, USA
}

*Corresponding author (e-mail: nirob@bgs.ac.uk)

\begin{abstract}
The continental crust is the primary archive of geological history, and is host to most of our natural resources. Thus, the following remain critical questions in Earth Science, and provide an underlying theme to all of the contributions within this volume: when, how and where did the continental crust form? How did it differentiate and evolve through time? How has it has been pre- served in the geological record? This introductory review provides a background to these themes, and provides an outline of the contributions contained within this volume.
\end{abstract}

The Earth is covered by a bimodal distribution of thin oceanic crust $(5-15 \mathrm{~km})$ and thick continental crust $(30-70 \mathrm{~km})$. While basaltic magmas can be found on all of the terrestrial planets, including the Moon, the andesitic to granitic continental crust appears to be unique within our Solar System (Campbell \& Taylor 1983). The continental crust is also far more ancient than the oceanic crust. The oldest areas of continental crust are c. $4 \mathrm{Ga}$ old with single zircon crystals as old as $4.4 \mathrm{Ga}$ (Wilde et al. 2001; Crowley et al. 2005; Harrison 2009; Hawkesworth et al. 2010). In contrast, the oldest oceanic crust is less than $250 \mathrm{Ma}$ old. Thus, the con- tinental crust is the primary archive of the Earth's geological history. Furthermore, the continents are where we live and where most of the natural resources that we use are stored. Not surprisingly, when, how and where the continental crust formed are critical questions in Earth science. A clear con- sensus has not been reached on many of these ques- tions about the formation of the continental crust, and they remain topics of active debate (Bowring

\& Housh 1995; Condie 1998; Nutman 2001; Rino et al. 2004; Martin et al. 2005; Valley et al. 2005; Watson \& Harrison 2005; Van Kranendonk et al. 2007b; Hawkesworth et al. 2010; Kemp et al. 2010; Roberts 2012). In addition to understanding its formation, understanding how the continental crust differentiated and evolved through time, and how it has been preserved in the geological record are key topics. These questions are central themes underlying all of the contributions within this vol- ume. The purpose of this introductory paper is to provide a brief background to these themes, and to provide an outline of the contributions contained within this volume.

\section{The continental crust}

The continental crust is typically divided into a two- or three-layer structure based on geochemical and geophysical modelling, and on studies of rare, exposed, crustal sections, featuring upper and lower + middle crust (e.g. Rudnick \& Gao 2003). The upper crust is dominated by sedimentary basins, igneous intrusions and volcanic rocks, and metamorphosed equivalents of these. The lower crust is more enigmatic, but is generally thought to be mafic in composition, comprising granulitic min- eral assemblages. The middle crust is transitional between the upper and middle crust, is probably formed from amphibolite-facies mineral assem- blages, and comprises predominantly igneous intrusions and lesser metamorphosed sedimentary and volcanic rocks (Fig. 1).

The average continental crust is andesitic in composition $\left(60.1 \% \mathrm{SiO}_{2}\right.$; Rudnick \& Fountain 

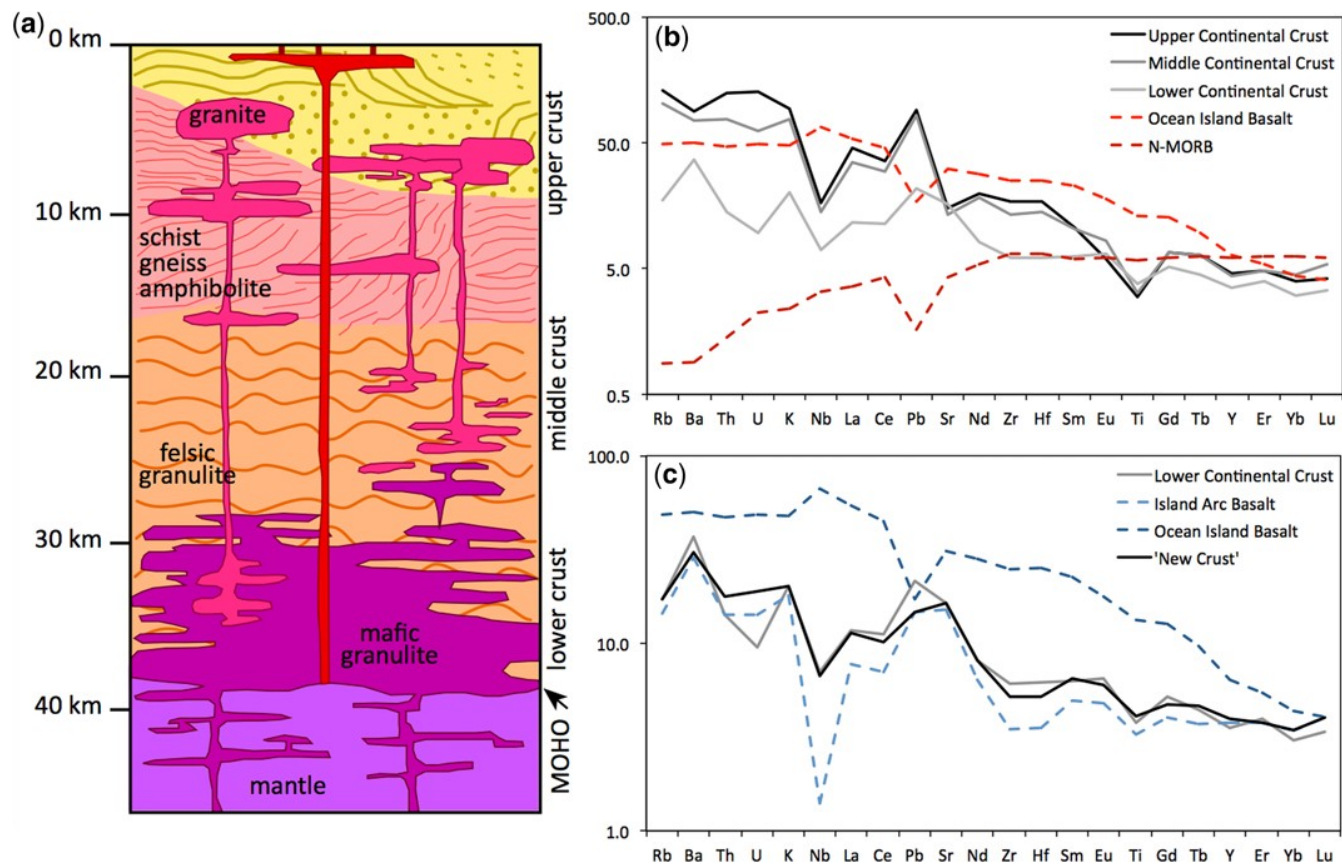

Fig. 1. (a) Simplified cross section of the continental crust (after Cawood et al. 2013). (b) Geochemical composition of the continental crust shown as primitive mantle normalized plots. Upper, middle and lower continental crust averages are from Rudnick \& Gao (2003); Ocean Island Basalt and N-MORB are from Sun \& McDonough (1989). (c) Lower Continental Crust compared to that of Ocean Island Basalt, Island Arc Basalt and 'New Crust' (Hawkesworth \& Kemp 2006), see text for explanation.

1995). In general, the upper continental crust is more Si- and K-rich (granitic) than the lower crust, which is more basaltic in composition (see Fig. 1). Andesitic magmas are primarily found in subduction zones, and so from the first recognition of plate tectonics, the formation of continental crust has been linked to subduction (Gill 1981). The early debates centred around whether andesitic melts were produced by melting the downgoing slab (which was being heated as it subducted) or by melting in the mantle wedge (which was being cooled but also hydrated by the slab). Early exper- imental studies of mantle melting supported the idea that the andesitic continental crust was pro- duced by direct melting of mantle wedge fluxed by $\mathrm{H}_{2} \mathrm{O}$ released from the downgoing slab (Kushiro 1974). However, more recent experimental studies have shown that hydrous melts of the Earth's peri- dotitic mantle are basaltic (Gaetani \& Grove 1998; Parman \& Grove 2004).

This creates a major mass balance problem. If the magmatic inputs into the continental crust are basaltic, how then did it acquire its andesitic compo- sition? There is no clear answer at this point (e.g. Taylor 1967; Taylor \& McLennan 1985; Kelemen 1995; Hawkesworth \& Kemp 2006). The most widely held view is that basaltic magmas pond at the crust-mantle interface (MOHO), which is a major density boundary (Jagoutz \& Behn 2013). There they cool and crystallize, forming dense amphibole, olivine and garnet cumulates, pushing the magma composition towards andesitic compo- sitions (e.g. Rudnick 1995). The dense cumulates are negatively buoyant and eventually sink back into the mantle, leaving the continental crust andesi- tic (Bird 1979; Kay \& Kay 1993). Basalts that fully crystallize at the $\mathrm{MOHO}$ and then subsequently melt would produce the same result of andesitic melts and dense residues (Rapp \& Watson 1995). Other ideas include melting of the eclogitic subducting crust (Drummond \& Defant 1990), Si addition to the mantle wedge from the slab (Kelemen et al. 1998) and direct accretion of buoyant felsic material that has been recycled through the mantle and risen through diapirism (Hacker et al. 2011).

The continental crust is enriched in incompatible elements compared with midocean ridge basalts (MORB). In particular, the large ion lithophile elements (LILE: $\mathrm{Rb}, \mathrm{Cs}$, Th, ) are strongly enriched, as are the light rare earth elements (LREE: La, Ce, Sm; see Fig. 1). Relative to the LILE and LREE, the high-fieldstrength elements ( $\mathrm{Nb}, \mathrm{Ta}$, 
$\mathrm{Zr}, \mathrm{Hf}, \mathrm{Ti})$ are strongly depleted in the continental crust (Pearce et al. 2005). This is a unique chemical signature of subduction zone magmatism and strongly implies a causal relationship. Hawkesworth

\& Kemp (2006) showed that the composition of the lower continental crust can be generated by addi- tion of $8 \%$ Ocean Island Basalt composition to that of $92 \%$ average Island Arc Basalts ('New Crust' in Fig. 1). The depleted mantle (as reflected by N-MORB, normal Mid Ocean Ridge Basalt; Fig. 1) is depleted in LILE and LREE. Adding the continental crust back into the depleted mantle would make it nearly chondritic in composition, indicating that it was extracted from the mantle by partial melting (Hofmann 1988), and is not, for example, the remnant of a flotation crust as seen on the Moon.

\section{Tectonic settings}

Continental crust can form in different tectonic environments; the relative contribution of these to the total current crustal budget has been esti- mated by various workers (e.g. Clift \& Vannucchi 2004; Scholl \& von Huene 2007, 2009; Clift et al. 2009; Stern 2011). Figure 2 shows an estimate of fluxes between different crustal reservoirs, and reveals that the majority of new continental crust is currently made in volcanic arcs (c. 75\%). The accretion of oceanic plateaux makes up most of the rest, and addition through continental intraplate magmatism only makes up a very small component (Clift et al. 2009).

Volcanic arcs are typically divided into island arcs and continental arcs. Intra-oceanic island arcs are those built entirely on oceanic crust, and account for some $40 \%$ of active subduction zones today (Leat \& Larter 2003). Growth of continental crust can occur in both island and continental arcs, but modelling shows that newly formed oceanic arcs have the greatest volume of juvenile growth (Stern

\& Scholl 2010). Continental arcs such as those of the Andes feature continental growth through mag-matic addition, with the long-term rates of magma production being similar to that in island arcs (Clift et al. 2009; DeCelles et al. 2009). Magma pro- duction is increased in continental arcs during high- flux periods ('flareups'), although the rate of new continental growth may not be significantly altered since these events involve the reworking of preexisting crust (DeCelles et al. 2009).

The creation of continental crust at the base of volcanic arcs is difficult to observe geologically, as there are few exposures of lower arc crust. How- ever, substantial advances have been provided by recent studies of the accreted island arcs of Talkeetna and Kohistan, which provide excellent expo- sures of both upper and lower arc crust (Petterson

\& Treloar 2004; Jagoutz et al. 2006; Debari \& Sleep 1991; Greene et al. 2006). In general, these studies support the idea that the continental crust is formed by differentiation of basaltic inputs. The arc crust sections exhibit a relatively simple stratigraphy formed by igneous differentiation of mantle-derived material. Simplified, this comprises, from top to bottom, volcanic rocks, upper-crustal intrusions, mid-crustal intrusions and lowercrustal cumulates (Fig. 3). It is more difficult to observe the lower crust within thicker continental arcs, but xenoliths reveal that they are also dominated by cumulate assemblages formed by magmatic differentiation (Ducea \& Saleeby 1998). The creation of this pri- mitive continental crust occurs through process- ing and maturation of initially mafic crust (e.g. Tatsumi et al. 2008; Stern \& Scholl 2010). This process is currently ongoing in island arcs of the western Pacific. In the Izu-Bonin arc, seismic studies have revealed a felsic middle crust, and a stratigraphy that is similar to that of the exposed Kohistan/Talkeetna arc sections (see Fig. 3). Col- lision of an oceanic arc with a continental margin

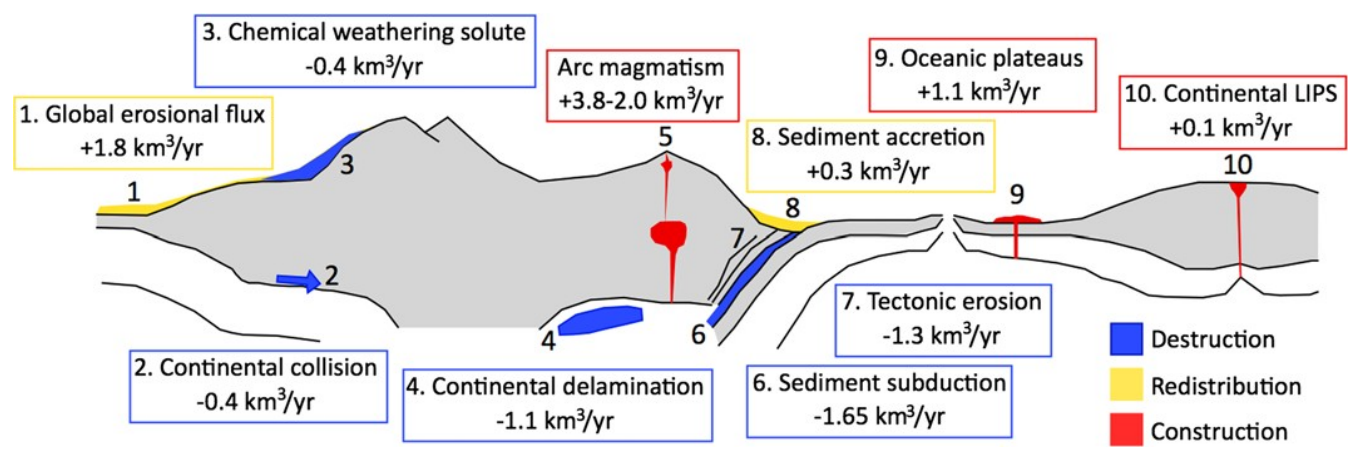

Fig. 2. Mass balance model of crustal additions and losses in different tectonic settings for the Cenozoic (after Clift

et al. 2009). 
(a)
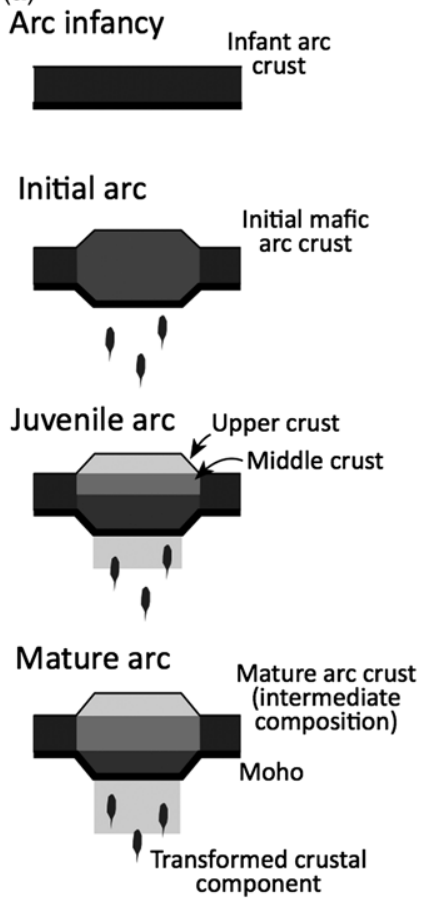

(b)

\section{Izu-Bonin arc section}

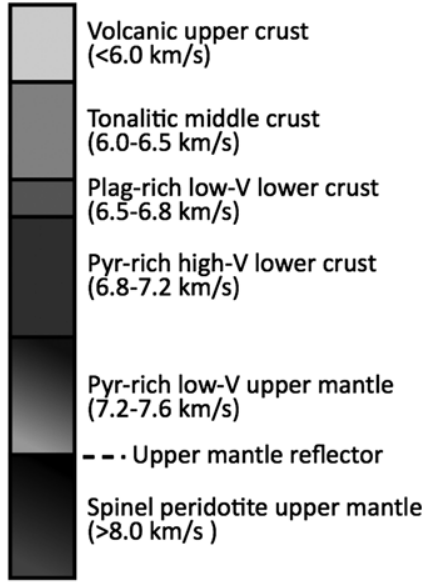

(c) Talkeetna arc section

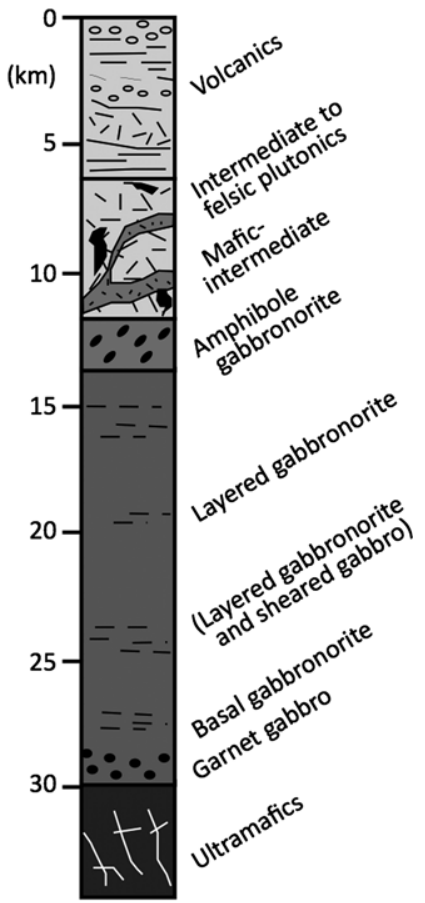

Fig. 3. (a) Simplified model of crust generation in island arcs (after Stern \& Scholl 2010; Tatsumi et al. 2008). (b) Izu- Bonin arc section based on seismological studies (after Kodaira et al. 2007; Takahashi et al. 2007). (c) Talkeetna island arc stratigraphy based on field and petrological observations (after Greene et al. 2006).

is associated with voluminous enriched magmatism that acts to displace the bulk composition of the accreted crust towards andesitic averages (Draut et al. 2002). During later continental collision, the layered stratigraphy of the continental crust is deformed, folded and interleaved, so that orogenic belts have a more complicated architecture of crustal lithologies and assemblages.

Rather than being discrete events, it is recog- nized that individual magmatic arcs are parts of a longer cycle of convergent margin tectonics that occurs in accretionary orogens. Although accretion- ary orogens differ greatly in their geometry, size and lifespan, there are key features common to all of them. One of these is the accretion of island arcs to continental margins. This may occur through the simple accretion of oceanic arcs to a passive or active margin (Brown et al. 2011; Draut \& Clift 2013), as most clearly demonstrated in modern Taiwan (Teng 1990; Byrne et al. 2011). However, arc accretion may occur though a more complex cycle of rifting of continental crust to form fringing arcs and ribbon continents, and the re-accretion of these to the continental margin, as has been observed in the western US Cordilleran margin
(Fig. 4; Busby 2004; Lee et al. 2007). Briefly, sub- duction rollback and trench retreat lead to extension of the continental margin and formation of a fringing island arc that hosts mafic to intermediate magmatism. Subsequent trench advance leads to accretion of this island arc to the continental mar- gin. After accretion occurs, continued compression will lead to crustal thickening. It is during this latter stage when large volumes of felsic magmatism are produced. Dense garnetbearing cumulates will form and may eventually delaminate; the return of this mafic crust to the mantle drives the overlying crust to a more felsic average composition (Lee et al. 2007). Similar delamination of lower crust occurs during crustal thickening in Taiwanstyle arc-continent collision zones (Clift et al. 2003). In this model, the two-stage process of crust for- mation mentioned previously is driven by horizontal tectonics; that is, basalt-andesite crust is extracted from the mantle above subducting plates to form island arcs, and differentiation to felsic magmatism occurs upon maturation of the arc in a thickened continental setting.

Volcanic plateaux comprise a large fraction of current crust production (see Fig. 2). The accretion 


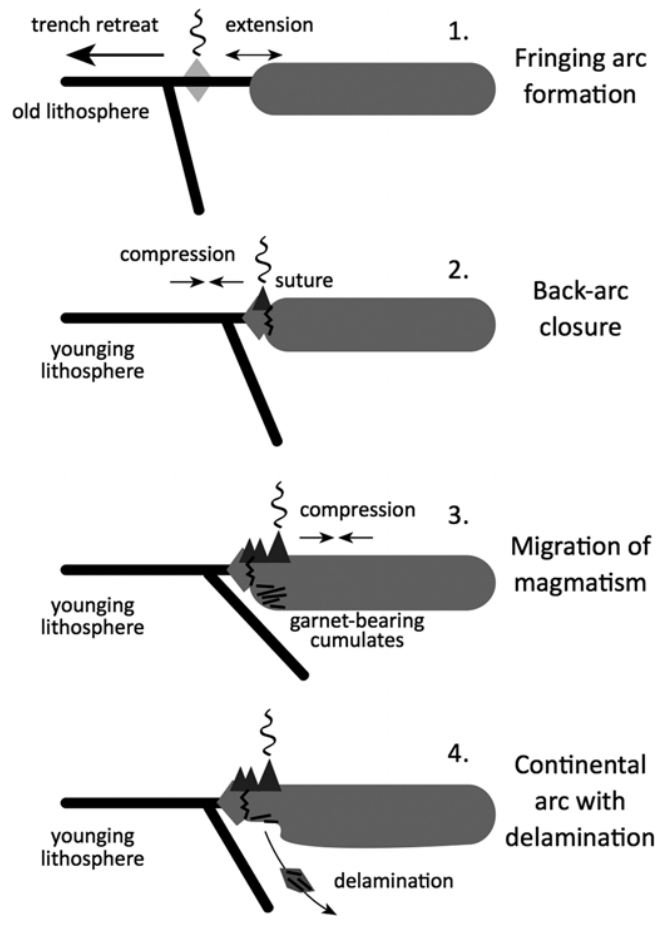

Fig. 4. Model of continental crust formation based upon rifting and accretion of fringing arcs, as observed in the Western US Cordillera (after Lee et al. 2007).

of these to continental margins within accretionary orogens will typically lead to maturation and dif- ferentiation of the crust, as with the aforementioned accretion of arcs (White et al. 1999; Kerr et al. 2000). Thus, although volcanic plateaux are gener- ally thought of as forming in intra-plate settings above mantle upwellings, many of the largest occur in oceanic settings and their addition to the growth of continental crust is thereby via convergent mar- gin processes. A key question is how large an ocea- nic plateau has to be before it can become accreted as opposed to being subducted and recycled into the upper mantle, as is the case with oceanic sea- mount chains (Cloos 1993). Continental Large Igneous Provinces (LIPs) and rift-related volcanism also contribute to the growth of the continents, but the volumes are minor compared with arc volcanism and oceanic plateau accretion (Fig. 2).

\section{Uniformitarianism}

The fluxes shown in Figure 2 are probably appli- cable to the last $200 \mathrm{Ma}$ or so (Scholl \& von Huene 2007; Clift et al. 2009). A fundamental observation is that the rate of additions $\left(4.9-6.7 \mathrm{~km}^{3} \mathrm{a}^{21}\right)$ roughly balance the rate of removal $\left(4.5 \mathrm{~km}^{3} \mathrm{a}^{21}\right)$.
At present, there appears to be little to no net crustal growth! This requires that growth rates in the past were higher than today, either because the rate of addition was greater, or because the rate of removal was lower, or some combination of both (Hawkesworth \& Kemp 2006). Thus, a key question is how has this balance of crustal growth in different settings changed through time? Condie \& Kröner (2013) have examined accretionary orogens in detail to determine the make-up of crust generated in different settings (see Fig. 5). Their study shows that continental arcs make up the greatest proportion of crust, and that this greatly outweighs oceanic islands arcs. This may in part be due to the fact that island arcs are not always preserved, but as shown in Figure 4, may be transformed into continental arcs upon their accretion to a continental margin. Although these accreted terranes can some- times be recognized, it is possible that they will go undetected in ancient orogens and be categorized as continental arcs. This is also true for oceanic plateaux, and thus the estimates for both oceanic plateaux and oceanic arcs may be minima. Magma- tism related to continental rifts and even continental flood basalt provinces is also minor, agreeing with the mass balance shown in Figure 2.

Figure 5 shows the variation in the geological constituents of accretionary orogens as a function of age, ranging from the Cenozoic (Sundaland), to the PalaeoproterozoicMesoproterozoic (SW North America). There appears to be a general decrease in the proportion of continental arcs from old to new. However, if microcratons are ignored, as these themselves must have originated as crust formed in a particular setting, then it can be seen that the general dominance of continental arc settings has not changed greatly through time. Extending this diagram into older orogens would be of great use, but is significantly hampered by the fact that it becomes increasingly difficult to recognize and dis- tinguish lithological characteristics in ancient orogens that can be used to determine the origin of different units.

Another reason why Figure 5 cannot be extended throughout Earth history with confidence is that the actual processes by which crust generation and reworking occur become more indiscriminant and more

debated as we look past c. $2.5 \mathrm{Ga}$. This is part a consequence of the ongoing debate

concerning when plate tectonics started, with estimates for its onset ranging from the

Hadean to the Neoprotero- zoic (e.g. Smithies et al. 2007; Harrison 2009; Stern 2005, 2008; Dhuime et al. 2012; Hamilton 2011; Shirey \& Richardson 2011; Van Kranendonk 2011).

Although some workers advocate similarities to the modern day (e.g. Harrison 2009), there is a gen-eral consensus amongst many that the Hadean (c.

4.56-4.0 Ga) was characterized by crust formation 


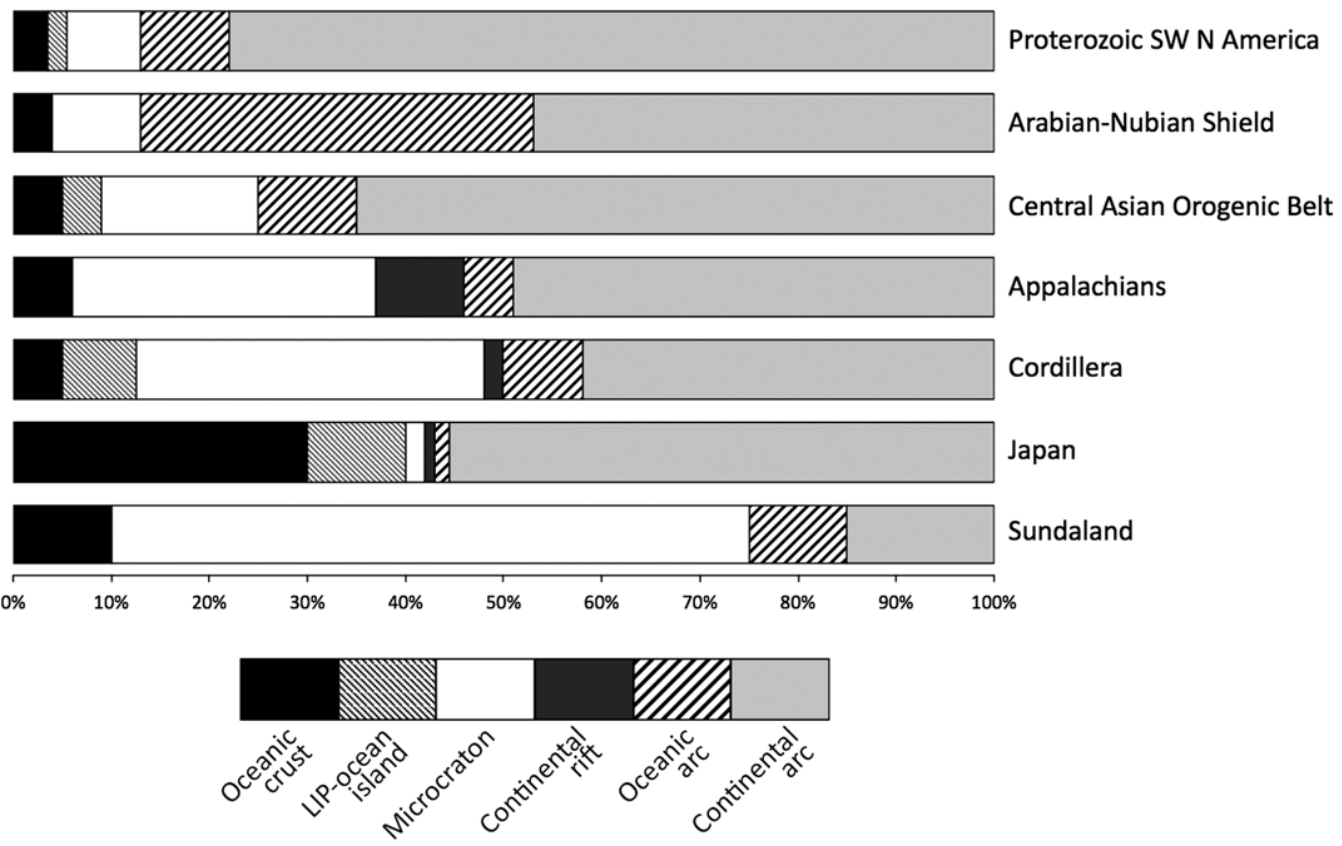

Fig. 5. The contribution of different units within accretionary orogens (after Condie \& Kröner 2013).

via processes different from today. The original mafic crust that covered the Earth after its forma- tion must have at some point begun to differenti- ate to produce more felsic components. It is within the Hadean that this probably first occurred, as evidenced by the geochemical characteristics of Hadean zircons found as detrital grains within Mesoarchaean metasedimentary rocks (e.g. Wilde et al. 2001; Valley et al. 2014). These zircons provide the only direct evidence of potential crust- forming processes at this time, and the interpretation of such limited evidence is highly debated. Nebel et al. (2014) recently reviewed the evidence from the Hadean zircons (see also Roberts \& Spencer 2014), and provided a model that aimed to encapsu- late all of the available evidence. Their model (see Fig. 6a; also Kemp et al. 2010) features a thick mafic protocrust that is altered by surficial processes, including water. Vertical tectonic pro- cesses have been proposed for this period and feature plumes of hot mantle that led to koma- tiite- basalt lava eruptions and down-sagging (i.e. the sagduction, or dripping-down) of crust as a result of continued magmatic accretion associated with stationary 'heat pipes' (Moore \& Webb 2013). In these models, low-degree felsic melts are minor and generated in regions where the mafic crust extends beyond c. $7008 \mathrm{C}$ geotherms. It is possible that horizontal tectonic processes were also active at this time, although a driver for this is not apparent in the mafic protocrust model, since plate move- ments today are driven by sinking of dense mafic plates below buoyant felsic plates. However, verti- cal movements would also lead to horizontal expan- sion and small-scale burial and thickening of crust, which may have led to crustal melting to produce felsic compositions.

The earliest fragments of continental crust are of Archaean age $(4.0-2.5 \mathrm{Ga})$. Only two fragments of early Archaean crust survive - the 4.0 Ga Acasta gneisses (Bowring et al. 1989) and the $3.9 \mathrm{Ga}$ Isua supracrustal belt (Moorbath et al. 1973; Nutman et al. 1996). Larger areas of 3.7-3.4 Ga crust are preserved in the Pilbara and Kaapvaal cratons and provide the clearest view of early crustal growth (Van Kranendonk 2010). By 2.7 Ga, fairly large areas of continental crust are exposed in the Supe- rior, Yilgarn and Belingwe cratons, amongst others. Archaean crust is somewhat different in character than modern continental crust. It is dominated by $\mathrm{K}$-poor (grey) granitic rocks of the tonalitetrondjemite- granodiorite (TTG) suite. Interspersed amongst the large areas of TTG are greenstone belts composed of supracrustal volcanic and sedimentary rocks. (Windley \& Bridgwater 1971).

Evidence for some form of plate tectonics is found as far back as $3.6 \mathrm{Ga}$, in rocks from the West Greenland part of the North Atlantic Craton (Polat et al. 2002; Nutman et al. 2002, 2007), and becomes more common through time. However, it 
(a)

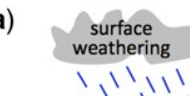

vertical processes

Hadean

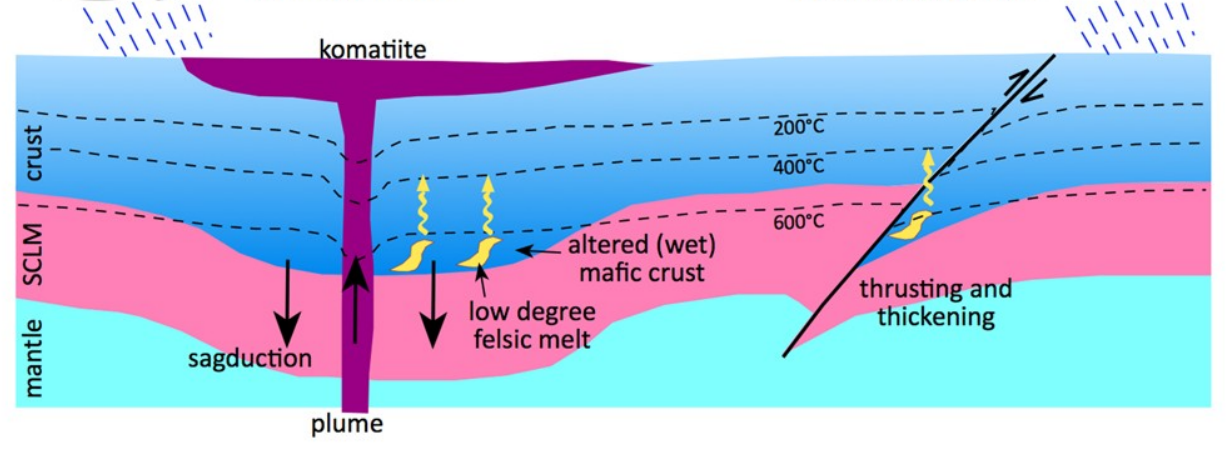

(b)

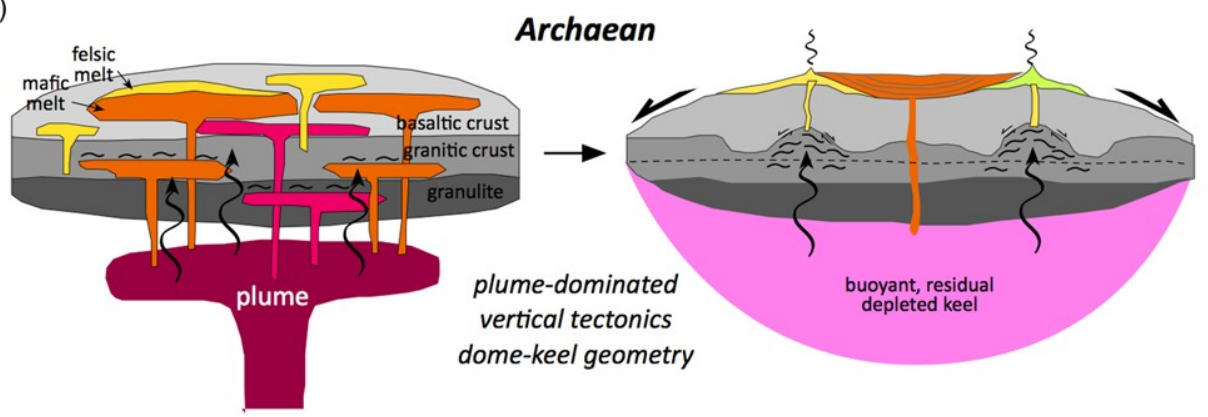

(c)

tectonic imbrication at convergent plate boundary

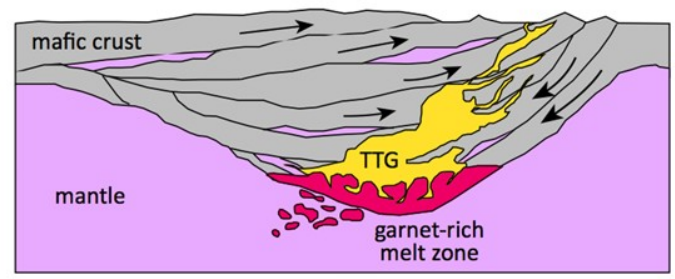

(d)

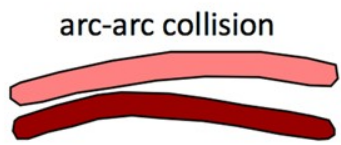

Formation of proto-continents through amalgamation of proto-arcs and orogenic belts
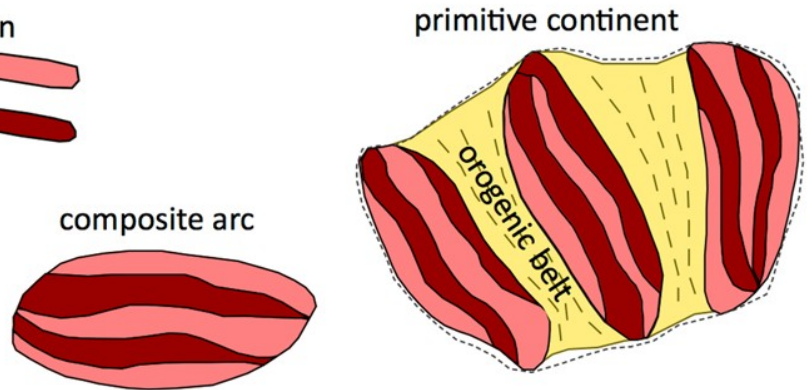

Fig. 6. (a) Model of Hadean crust formation comprising mafic protocrust and small amounts of low-degree felsic melts (modified from Nebel et al. 2014). (b) Plume-dominated Archaean crust formation that may have dominated the early Archaean, with eruption and intrusion of mantle-derived mafic magmas and infracrustal reworking to form felsic magmas. Vertical tectonics is dominant, and leads to a dome and keel structure (modified from Van Kranendonk et al. 2011). (c) A model of crust formation in 'proto-arcs' that may have arisen in the early Archaean, featuring imbrication of oceanic crust rather than deep subduction, and production of felsic magmas from deep melting of mafic crust (after Nutman et al. 2007). (d) The amalgamation of 'proto-arcs' into primitive continents through their accretion and collision (after Santosh et al. 2009). 
is widely considered that plate tectonics in the Palaeoarchaean (at least) differed from the modern style of steeply dipping slabs of old, cold oceanic lithosphere, owing to thicker, more buoyant ocea- nic crust, and higher mantle heat flow that resulted in smaller plates colliding across shallow-dipping subduction zones (Bickle 1978; Davies 1992; Martin et al. 2005; Van Kranendonk 2011).

The generation of Archaean granitegreenstone crust is more controversial, but there is growing con- sensus that both plate tectonics and mantle plumes played a role in the formation of this type of crust (e.g. Polat et al. 1998; Percival 2007; Van Kranen- donk et al. 2007a, b, 2014; Van Kranendonk 2010; Smith et al. 2012; Bédard et al. 2013). Higher man- tle heat and more radiogenic-bearing granitic rocks created overall more mafic and less rigid crust, characterized by thick volcanic successions dominated by basaltic and komatiitic lavas, with subordi- nate felsic volcanic rocks and lesser volumes of sedimentary rocks compared with post-Archaean crust. Granitic rocks in granitegreenstone terrains are dominated by TTG, but rather than having been derived exclusively from subducted oceanic crust as in modern subduction settings, a number of stud- ies indicate a more varied origin for Archaean TTG, largely through infracrustal melting (Fig. 6b-c; Martin et al. 2005; Champion \& Smithies 2007; Smithies et al. 2009; Zeh et al. 2011; Bédard et al. 2013). Indeed, a number of Archaean granite- greenstone terrains are interpreted as volcanic pla- teaux, either truly oceanic or built on a substrate of older, at least in part sialic, crust (Fig. 6b; Polat et al. 1998; Van Kranendonk et al. 2007a, 2014; Tessa- lina et al. 2010; Reimink et al. 2014). The timing of the first true continents is difficult to ascertain, whether continental crust was derived in arc environments or in volcanic plateaux, it would require significant global plate motions to amalgamate these into large continental blocks (Fig. 6d; Santosh et al. 2009). Certainly by the late Archaean, the geological record suggests that many large continents or cratons had formed (Bleeker 2003).

\section{Growth rate}

The rate at which continental crust has been gener- ated has long been debated. Two significant features that have been observed in the geological record are that crustal growth rate comprises a strong episodi- city and that the crustal growth rate has slowed through time. The episodic nature of crustal growth is evident in compilations of age, model age and iso- topic compositions of minerals and rocks (e.g. Gastil 1960; Condie 1998; Kemp et al. 2006; Parman

2007; see Fig. 1, Roberts \& Spencer 2014). Model- ling of growth rates based on these compilations has led many to the conclusion that the current volume of continental crust was achieved very early on in Earth history (e.g. Armstrong \& Harmon 1981), or that a large proportion was formed by the end of the Archaean (Belousova et al. 2010; Dhuime et al. 2012). The control on growth rate will be the balance between different settings of continental addition $v$. continental loss (see Fig. 2). This bala- nce will change through orogenic cycles (Collins et al. 2011; Roberts 2012; Roberts \& Spencer 2014, see Fig. 9), and through supercontinent cycles (Hawkesworth et al. 2009; Spencer et al. 2013). Some workers have speculated that crustal growth rate will increase during supercontinent formation (Condie 1998), whereas others have suggested an increase during supercontinent breakup (Stern \& Scholl 2010; Roberts 2012, 2013). The direct role of mantle plumes (upwellings) and avalanches of subducting slabs into the mantle (downwellings) upon crustal growth remains contested (Stein \& Hofmann 1994; Condie 1998; Rino et al. 2004; Arndt \& Davaille 2013), but mantle convection plays a role regardless, since it is intrinsically linked to the supercontinent cycle.

\section{Contributions to this volume}

This volume comprises 13 contributions that use a range of methods to study the evolution of the con- tinental crust. Two review papers, O'Neill et al. and Roberts \& Spencer, use contrasting methods - numerical modelling and detrital zircon isotopes, respectively - to look at continent formation from a global perspective throughout geological history. Papers by Bastow et al. and Piper use alternative geophysical methods - seismology and palaeomag- netism, respectively - to look at geodynamics during the Proterozoic and Archaean. Four papers, Van Kranendonk et al., Nutman et al., Dey et al. and Kleinhanns et al., use a combination of field- based studies and primarily geochemistry and geochronology to look at processes of continent formation from the Palaeoarchaean to the Palaeoproterozoic. Six further contributions use insitu zircon isotope analyses to determine the crustal evolution of different regions ranging in age from the Eoarchaean to the Phanerozoic.

The balance between different techniques across these contributions is probably a fair representation of the current and recent literature. On one hand, zircon-based and geochemical studies are easily accessible and affordable to those with access to lab- oratories, whereas on the other hand, large seismic networks and lengthy field-based studies can be expensive and time-consuming ways of data collec- tion. However, both have increased our knowledge of the continental crust and its history, and future 
research to further our understanding will continue to require a wide range of integrated methods and expertise.

\section{Geophysics and numerical modelling}

O'Neill et al. (2013) investigate the episodic nature of Earth's geological record through numerical modelling, providing a comprehensive review of some of the major features of Earth's evolution, such as magmatism, orogeny and plate motion. Although the rock record is perhaps affected by selective preservation (e.g. Hawkesworth et al. 2009, these authors argue that records of mantle evolution - such as the Helium depletion record (Parman 2007) - are primary records of episodic tectonic behaviour varying between plate tectonic and stagnant lid modes. The authors use a number of geodynamic numerical models to help understand the possible causes and effects of such episodic behaviour on Earth, and find that the dynamics of subducting slabs are a likely source. Numerous mechanisms are proposed, but at present, the domi- nant mechanism is not constrained; these include episodic subduction, mantle avalanches and dyna- mics in the basalt-eclogite transition.

Bastow et al. (2013) present a geophysical study of Precambrian continental crust that contrib- utes to our understanding of the crustal structure of Archaean to Proterozoic regions; this study reviews the results from a seismic network deployed over little-known Precambrian crust of the Canadian Shield in the Hudson Bay area (the Hudson Bay Lithospheric Experiment). Receiver function ana- lysis reveals a different structure between Archaean and Proterozoic lithosphere, with the Archaean having a simple, uniformly thick felsic crust $(37 \mathrm{~km})$, and the Palaeoproterozoic crust (that of the Trans Hudson Orogen) having a thicker $(46 \mathrm{~km})$ and more complex structure. Additionally, an anisotropy study reveals platescale fabrics within the litho- sphere that are c. $1.8 \mathrm{Ga}$ in age, and interpreted as plate tectonic features formed at this time. The authors suggest that the Archaean crust in this region does not resemble crust made via arc and accretionary processes, but perhaps more probably by vertical accretion processes, such as plumes and delamination.

Piper $(2013 b)$ reviews palaeomagnetic data for the Neoproterozoic era, and uses this as a basis for discussion of plate tectonics through time. Piper's compilation of palaeomagnatic poles for $0.8-$

$0.6 \mathrm{Ga}$ shows that these conform to a single apparent polar wander path, which he uses as support for a model whereby the continents at this time were not individually moving, as in a traditional plate tec- tonic regime, but were part of a supercontinental lid.
This work builds on Piper's previous posit that the continents have been part of a large continental lid since the Archaean ('lid tectonics'), and that modern-day-style plate tectonics did not start until after $0.6 \mathrm{Ga}$ (Piper 2013a).

\section{Geology and geochemistry}

Van Kranendonk et al. (2014) review the processes of crust formation over the period 3.5-

3.2 Ga in the Pilbara (Australia) and Kaapvaal (southern Africa) cratons. They discuss and com- pare the stratigraphy, structure, petrology and geo- chemistry of these terranes, and find that vertical tectonic processes dominate over horizontal pro-cesses. These authors provide a model for crust generation that involves a thick volcanic plateau that develops via voluminous mantle-derived mag- matism, and involving the formation of dome-and- keel structure in the upper to mid crust as a result of a process known as Partial Convective Over- turn. Tonalite-trondjemite- granodiorite suites in this model are inferred to form from infracrus- tal melting. Mantle-derived magmatism includes komatiite- basalt eruptions, and delamination of eclogitic residues drives further crustal differen- tiation. In this model, a thick depleted (and buoy-ant) mantle lithospheric keel is formed via melt depletion, synchronous with crustal growth, aiding the preservation of continental crust formed in this manner. The authors caution, however, that Palaeo- archaean crust generation was not exclusively through these processes, and that complementary horizontal subduction-related processes were likely to be contemporaneous, before they became more dominant after 3.2 Ga.

Nutman et al. (2013) discuss continentforming processes in the Eoarchaean. They present a review of geochemical, geochronological and lithological relations from the Isua Supracrustal Belt of west Greenland. These authors present a model of crust formation in what they term 'proto-arcs'. These proto-arcs have similarities to modern island arcs, in that oceanic crust is subducted, and buoyant intermediate-felsic crust is generated in the over- riding plate. The major differences in the model of proto-arcs to modern-day arcs are that shallow sub- duction leads to stacking and imbrication of oceanic plate fragments, rather than deep subduction into the asthenosphere, and that felsic magmatism is domi- nated by tonalite-dacite compositions that are formed by melting of metamorphosed mafic rocks. A corollary of the proto-arc model is that, since the residues of TTG crust generation would not have been recycled into the mantle, the generation of a depleted mantle reservoir in terms of Lu-Hf would be delayed. 
Dey et al. (2013) present a study of continent formation in the eastern Dharwar craton of India, using geochemical and geochronological data from the Neoarchaean Kadiri Greenstone Belt. The belt comprises basalts, andesites and dacites/rhyolites, which are interpreted as forming through plumerelated oceanic plateau magmatism, suprasubduc- tion continental arc magmatism, and deep intra-arc crustal-melt-related magmatism, respectively. A model is proposed whereby an oceanic plateau col- lided with a continental arc, and subsequent crustal thickening in a compressional regime led to exten- sive crustal melting. These authors advocate a 'hot orogen' scenario for this setting, and their results imply similarities between the Neoarchaean geodynamics with modern-day-style plate tectonics.

Kleinhanns et al. (2013) present a geochrono- logical and geochemical study of the Kamanjab Inlier, a Palaeoproterozoic region within NW Namibia. The region in question is located on the edge of the Congo Craton. Granitoids formed in the 1.86-1.83 Ga time period, and have geochemis- try that is interpreted as a result of formation in a continental arc environment. Late-stage anatectic melts intruded the crust at a slightly younger time, at $1.80 \mathrm{Ga}$, and are proposed by the authors to have formed from watersaturated crustal melting coincident with hightemperature metamorphism. Granitoids with a similar history are found in other basement complexes along the Congo Craton, sug- gesting the accretion of at least a $1500 \mathrm{~km}$ length of magmatic arc onto its margin at $2.0-1.8 \mathrm{Ga}$. The described setting and processes of continent formation lack any contrasts from those occurring in the Phanerozoic.

\section{Zircon}

Roberts \& Spencer (2014) present a review of the major contributions that zircon-based studies have had on our understanding of continental evolu- tion. Topics covered include the style of continent formation in the Hadean and Archaean, the onset of plate tectonics and subduction, the rate of crus- tal growth and the preservational bias that may exist in the zircon record. The authors argue that changes in geodynamic regimes occurred at 4.0 and $2.5 \mathrm{Ga}$, and mark the onset of an Archaean geodynamic environment and a more modern-daystyle one with collisional orogenesis and supercontinents, respectively. The Archaean regime is not explicit from the zircon data alone, but features continuous juvenile growth across different regions, and a gradual change to subduction-dominated continent formation. Individual orogens feature variable crus- tal growth rate, based on the balance between crus- tal growth and crustal destruction (return to the mantle). The balance of these orogens, and thus crustal growth rate, is shown to be controlled by the supercontinent cycle.

Claesson et al. (2014) present an isotopic study of Archaean domains exposed in the Ukrainian Shield to understand the crustal evolution of this region. Both the Podolian and Azov domains of this shield contain Eoarchaean (c. $3.75 \mathrm{Ga}$ ) com- ponents, dated by $\mathrm{U}-\mathrm{Pb}$ and isotopic model ages. The zircon $\mathrm{U}-$ $\mathrm{Pb}$ data are variably discordant, but $\mathrm{Hf}$ isotopic compositions point to single sources with model ages around $3.75-3.9 \mathrm{Ga}$; this study highlights the utility of combining in-situ $\mathrm{U}-\mathrm{Pb}$ and $\mathrm{Hf}$ isotopes to understand heavily reworked rocks. A second episode of crust formation in the Azov domain is represented by zircons from meta- sedimentary rocks, with model ages of 3.25-

3.1 Ga. In the Podolian domain, zircon overgrowths caused by metamorphic events are dated at c. 2.8 and c. $2.04 \mathrm{Ga}$. The Podolian and Azov crustal domains have contrasting histories, and were thus probably amalgamated into the Ukrainian Shield during the later Archaean and Palaeoproterozoic. The authors make the point that Eoarchaean ages are now common in many cratons, and thus recon-structions of past continents (e.g. Bleeker 2003) cannot be based purely on the coincidence of $\mathrm{U}-\mathrm{Pb}$ ages.

Lancaster et al. (2014) study the timing of crust generation across cratons of the North Atlan- tic region. These authors use zircon data from a granitic unit and various sedimentary rocks from across NW Scotland to produce crustal extractions ages (model ages). The 4160-1420 Ma model ages from across the southern, central and northern regions of NW Scotland imply crust generation during the Eoarchaean, perhaps across multiple regions of basement. Crystallization ages range from 3670 to $1070 \mathrm{Ma}$, with peaks at 2700 and 1700 Ma. Similar distributions of crystallization and model ages are found in other regions across the North Atlantic, for example, Greenland, Canada and northern Scandinavia, suggesting that Eoarchaean crust generation may have been exten- sive across this region.

Petersson et al. (2013) study the timing of crust generation in SW Fennoscandia using zircon $\mathrm{U}-\mathrm{Pb}$ and $\mathrm{Hf}$ isotopes from various igneous units. The region in question was variably reworked during the Sveconorwegian orogeny at $1.1-0.9$ $\mathrm{Ga}$. These authors analyse zircons from 1800 to 1200 Ma gran-itoids that were formed in the preceding stages of accretionary orogenesis. Using the combined $\mathrm{U}-\mathrm{Pb}$ and $\mathrm{Hf}$ data, they show that early (c. $1800 \mathrm{Ma}$ ) granitoids were formed from crust mixed with a juvenile 2.1-1.9 Ga component. Furthermore, they show that subsequent magmatism to $1400 \mathrm{Ma}$ fea- tured reworking of this same crust, and that an 
influx of juvenile magma is recorded at 1200 Ma. The model for this region features a longlived accretionary margin, with magmatism in continental arc environments; this study indicates that magma- tism is dominated by crustal recycling, rather than crustal growth.

Boekhout et al. (2013) address continental growth along the pre-Andean convergent margin using a compilation of igneous and detrital zircon data. The authors compare changes in the $\mathrm{Hf}$-isotope compositions of zircons through time with the geo-dynamics of the continental margin and show a link between arc migration, slab retreat and advance, and the resulting isotopic composition of magmatism. The data show an overall trend towards more juven- ile compositions throughout much of the Phanero- zoic, which the authors interpret as recording an overall increase in continental growth rate. Trends in isotope space that represent a greater degree of crustal reworking correlate with known periods of slab advance within a compressional regime.

Hiess et al. (2014) study the genesis of Phanero- zoic paragneiss and orthogneiss units from the Western Province of New Zealand. The protoliths to the paragneisses are interpreted to be passive margin sediments deposited on the Gondwana margin. These rocks have variable trace element and isotopic signatures compatible with a range of sources. Devonian orthogneisses have hafnium and oxygen isotope signatures indicative of incorpor-ation of supracrustal materials to the magmatic pro- toliths and are compatible with deep melting and assimilation of older basement rocks by primitive arc magmas. One Cretaceous orthogneiss has a signature compatible with melting of a Devonian source. Other Cretaceous orthogneisses have more primitive signatures, and are interpreted to be related to extensional rift-related magmatism. This work shows that the chemical and isotopic compo- sition of gneisses can be retained through amphibo- lite-facies metamorphism, so that information on the protoliths can be gleaned through such studies.

\section{Summary and outstanding questions}

A general conclusion that may be drawn from the papers presented in this special volume is that there is more than one way to make continental crust, both within periods of geological time, as well as across geological time, with different contri- butions from primitive, or subduction-enriched, mantle and recycled continental crust depending on tectonic environment, lending unique character- istics to different regions. This variability naturally reflects the kind of variability found in the formation of recent (Phanerozoic) crust - from the typical mode of lateral accretion at convergent plate margins, to thick plateaux formed over hot spots, to more complex scenarios involving extension, transpression and transtension.

Perhaps the biggest, single advance in recent years is the recognition of the limitations of the uni-formitarian principle as applied to tectonics and crustal growth, particularly relating to early Earth. There in increasing evidence from a number of ter- rains that the onset of modern-style (i.e. steep and deep subduction of old, cold oceanic lithosphere) commenced at c. $3.2 \mathrm{Ga}$ (e.g. Smithies et al. 2005, 2007; Van Kranendonk 2010; Shirey \& Richardson 2011; Van Kranendonk 2011; Dhuime et al. 2012). Prior to the Mesoarchaean emergence of modern- style plate tectonics, it appears that, although subduction and plate tectonics were operative, the com- bination of higher mantle heat flow and resultant thicker oceanic lithosphere meant that subduction style was distinct, characterized by shallow dips and a lack of mantle wedge involvement in magma genesis (Smithies 2000; Foley et al. 2003; Martin et al. 2005; Nutman et al. 2013). A higher degree of mantle involvement in magmatism resulted in the formation of anomalously thick por-tions of continental lithosphere via construction as volcanic plateaux (e.g. Bastow et al. 2013; Van Kra- nendonk et al. 2014). As a counterpart, high-grade gneiss terranes were forming in settings where crust was recycling back into the mantle (e.g. Nutman et al. 2007, 2013; Van Kranendonk 2010). Over time, gradually decreasing mantle heat led to compositional changes in the subcontinental man- tle lithosphere (Griffin et al. 2009), reflecting (in part) changes in the style of continental crust for- mation and evolution of plate tectonic style (Sizova et al. 2014; Brown 2014). This secular change is highlighted by the other main advance in under- standing of planetary evolution, namely the poten- tially episodic nature of tectonics on Earth (and other planets; Turcotte 1993; Condie 1998; O'Neill et al. 2007, 2013). The style and rate of plate tectonics are now known to have changed over time, even through the Proterozoic and into the Phanero- zoic (Moores 1993; Van Kranendonk \& Kirkland 2013; Piper 2013a). Rates of crustal growth are vari- able on all scales, from individual orogens (e.g. Boekhout et al. 2013) to the entire global budget (Roberts \& Spencer 2014).

A third major advance in the understanding of continental growth over time is the increasing evi- dence of Eoarchaean crust involved in the formation and stabilization of continental lithosphere from many parts of the world (e.g. Claesson et al. 2014; Lancaster et al. 2014; Nutman et al. 2013). This has important implications for crustal growth models through time, with increasing evidence for very rapid, early growth of continental crust, followed by recycling. 
One of the major outstanding questions that affects our understanding of secular change in plate tectonics, estimates of crustal growth rate and associated episodic records of Earth evolution is the role of crustal preservation. It has been proposed that the episodic nature of many geological records locked up in the continental crust are biased, because the continental crust itself has been variably preserved through Earth's history (Cawood \& Hawkesworth 2013). Hawkesworth et al. (2009) present a conceptual model that links superconti- nent formation with the increased preservation of continental crust. Although the idea of preservation bias during orogenic and supercontinent cycles is yet to be fully tested and explored, it has long been postulated that much of the continental crust is recycled into the mantle and lost from the geologi- cal record (e.g. Armstrong 1968, 1991). Thus, the crust we observe and study today provides only a glimpse into the record of Earth history. Until we can be sure how representative this crust is, many aspects of our understanding of the evolution of con- tinental crust will have a prevailing uncertainty.

The authors would like to thank all of the contributors for their patience during the assembly of this special publication, and all the reviewers for their effort and constructive comments that benefited the individual contributions. A. Hills, R. Kriefman and T. Anderson of the Geological Society of London are thanked for their edi- torial and production handling. N.R. publishes with the permission of the Director of the British Geological Survey. M.V.K. acknowledges support from the University of New South Wales. This is publication number 498 of the ARC Centre of Excellence for Core to Crust Fluid Systems.

\section{References}

Armstrong, R. L. 1968. A model for the evolution of strontium and lead isotopes in a dynamic earth. Reviews of Geophysics, 6, 175-199.

Armstrong, R. L. 1991. The persistent myth of crustal growth. Australian Journal of Earth Sciences, 38, 613-630.

Armstrong, R. L. \& Harmon, R. S. 1981. Radiogenic isotopes: the case for crustal recycling on a near- steady-state no-continental-growth Earth [and discus- sion]. Philosophical Transactions of the Royal Society of London. Series A, Mathematical and Physical Sciences, 301, 443-472.

Arndt, N. \& Davaille, A. 2013. Episodic Earth evolution. Tectonophysics, 609,661-674.

Bastow, I. D., Eaton, D. W. et al. 2013. The Hudson Bay Lithospheric Experiment (HuBLE): insights into Precambrian plate tectonics and the development of mantle keels. In: Roberts, $\mathrm{N}$. M. W., Van Kranen- donk, M., Parman, S., Shirey, S. \& Clift, P. D. (eds) Continent Formation Through Time. Geological Society, London, Special Publications, 389, First published online November 27, 2013, http://dx.doi. org/10.1144/SP389.7

Bédard, J., Harris, L. B. \& Thurston, P. C. 2013. The hunting of the snArc. Precambrian Research, 229, 20-48.

Belousova, E. A., Kostitsyn, Y. A., Griffin, W. L., Begg, G. C., O'reilly, S. Y. \& Pearson, N. J. 2010. The growth of the continental crust: constraints from zircon $\mathrm{Hf}$-isotope data. Lithos, 119,457-466.

Bickle, M. J. 1978. Heat loss from the Earth: a constrain on Archaean tectonics from the relation between geothermal gradients and the rate of plate production. Earth and Planetary Science letters, 40, 301-315.

Bird, P. 1979. Continental delamination and the Colorado Plateau. Journal of Geophysical Research, 84, 7561-7571.

Bleeker, W. 2003. The late Archean record: a puzzle in

c. 35 pieces. Lithos, 71, 99-134.

Boekhout, F., Roberts, N. M. W., Gerdes, A. \& Schaltegger, U. 2013. A Hf-isotope perspective on continent formation in the south Peruvian Andes. In: Roberts,

N. M. W., Van Kranendonk, M., Parman, S., Shirey, S. \& Clift, P. D. (eds) Continent Formation Through Time. Geological Society, London, Special Publications, 389, First published online September 9 , 2013, http://dx.doi.org/10.1144/SP389.6

Bowring, S. A. \& Housh, T. 1995. The earth early evol- ution. Science, 269, 1535-1540.

Bowring, S. A., Williams, I. S. \& Compston, W. 1989. $3.96 \mathrm{Ga}$ gneisses from the Slave Province, Northwest- Territories, Canada. Geology, 17, 971 975.

Brown, M. 2014. The contribution of metamorphic petrol- ogy to understanding lithosphere evolution and geo- dynamics. Geoscience Frontiers, 5,553-569.

Brown, D., Ryan, P. D. et al. 2011. Arc-continent collision: the making of an orogen. In: Brown, D. \& Ryan, P. D. (eds) Arc- Continent Collision. Frontiers in Earth Sciences, 477-493.

Busby, C. 2004. Continental growth at convergent margins facing large ocean basins: a case study from Mesozoic convergent-margin basins of Baja Califor- nia, Mexico. Tectonophysics, 392, 241-277.

Byrne, T., Chan, Y. C., Rau, R. J., Lu, C. Y., Lee, Y. H. \& Wang, Y. J. 2011. The arc-continent collision in Taiwan. In: Brown, D. \& Ryan, P. D. (eds) Arc-Continent Collision. Frontiers in Earth Sciences, 213-245. Campbell, I. H. \& Taylor, S. R. 1983. No water, no gran- ites - no oceans, no continents. Geophysical Letters, 10, 1061-1064.

Research

Cawood, P. A. \& Hawkesworth, C. J. 2013. Temporal relations between mineral deposits and global tectonic cycles. In: Jenkin, G. R. T., Lusty, P. A. J., Mcdo- nald, I., Smith, M. P., Boyce, A. J. \& Wilkinson,

J. J. (eds) Ore Deposits in an Evolving Earth. Geological Society, London, Special Publications, 393, http:// dx.doi.org/10.1144/SP393.1

Cawood, P. A., Hawkesworth, C. J. \& Dhuime, B. 2013. The continental record and the generation of continental crust. Geological Society of America Bulletin,125,14-32.

Champion, D. C.\& Smithies, R. H. 2007. Geochemistry of Paleoarchean granites of the East Pilbara Terrane: implications for early Archean crustal growth. In: Van Kranendonk, M. J., Smithies, R. H. \& Bennet, V. 
(eds) Earth's Oldest Rocks: Developments in Precambrian Geology. Amsterdam, Elsevier, 15, 369-409.

Claesson, S., Bibikova, E., Shumlyanskyy, L., Dhuime, B. \& Hawkesworth, C. J. 2014. The oldest crust in the Ukrainian Shield Eoarchaean $\mathrm{U}-\mathrm{Pb}$ ages and $\mathrm{Hf}-\mathrm{Nd}$ constraints from enderbites and metasediments. In: Roberts, N. M. W., Van Kra- nendonk, M., Parman, S., Shirey, S. \& Clift, P. D. (eds) Continent Formation Through Time. Geological Society, London, Special Publications, 389, First pub- lished online January 3, 2014, http://dx.doi.org/10. 1144/SP389.9

Clift, P. \& Vannucchi, P. 2004. Controls on tectonic accretion v. erosion in subduction zones; implications for the origin and recycling of the continental crust. Reviews of Geophysics, 42, RG2001, org/10.1029/2003RG000127

Clift, P. D., Schouten, H. \& Draut, A. E. 2003. A general model of arc- continent collision and sub- duction polarity reversal from Taiwan and the Irish Caledonides. In: Leat, P. T. \& Larter, R. D. (eds)

Intraoceanic Subduction Systems: Tectonic and Magmatic Processes. Geological Society, London, Special Publications, 219, 81-98.

Clift, P. D., Vannucchi, P. \& Morgan, J. P. 2009. Crustal redistribution, crust- mantle recycling and Phanerozoic evolution of the continental crust. Earth- Science Reviews, 97, 80-104.

Cloos, M. 1993. Lithospheric buoyancy and collisional orogenesis: subduction of oceanic plateaus, continen- tal margins, island arcs, spreading ridges, and sea- mounts. Geological Society of America Bulletin, 105, 715-737.

Collins, W. J., Belousova, E. A., Kemp, A. I. \& Murphy, J. B. 2011. Two contrasting Phanerozoic orogenic systems revealed by hafnium isotope data. Nature Geoscience, 4,333337.

Condie, K. C. 1998. Episodic continental growth and supercontinents: a mantle avalanche connection? Earth and Planetary Science Letters, 163,97-108.

Condie, K. C. \& Kröner, A. 2013. The building blocks of continental crust: evidence for a major change in the tectonic setting of continental growth at the end of the Archean. Gondwana Research, 23, 394-402.

Crowley, J. L., Myers, J. S., Sylvester, P. J. \& Cox, R. A. 2005. Detrital zircon from the Jack Hills and Mount Narryer, Western Australia: evidence for diverse - $4.0 \mathrm{Ga}$ source rocks. Journal of Geology, 113,239-263.

Davies, G. F. 1992. On the emergence of plate tectonics.

Geology, 20, 963-966.

Debari, S. M. \& Sleep, N. H. 1991. High-Mg, low-Al bulk composition of the Talkeetna island arc, Alaska: implications for primary magmas and the nature of arc crust. Geological Society of America Bulletin, 103,37-47.

DeCelles, P. G., Ducea, M. N., Kapp, P. \& Zandt, G. 2009. Cyclicity in Cordilleran orogenic systems. Nature Geoscience, 2,251-257.

Dey, S., Nandy, J., Choudhary, A. K., Liu, Y. \& Zong, K. 2013. Neoarchaean crustal growth by combined arc-plume action: evidence from the Kadiri Green- stone Belt, eastern Dharwar craton, India. In: Roberts, N. M. W., Van Kranendonk, M.,
Parman, S., Shirey, S. \& Clift, P. D. (eds) Continent Formation Through Time. Geological Society, London, Special Publications, 389, First published online Sep- tember 2, 2013, http://dx.doi.org/10.1144/SP389.3

Dhuime, B., Hawkesworth, C. J., Cawood, P. A. \& Storey, C. D. 2012. A change in the geodynamics of continental growth 3 billion years ago. Science, 335, 1334-1336.

Draut, A. E. \& Clift, P. D. 2013. Differential preservation in the geologic record of intraoceanic arc sedimentary and tectonic processes. EarthScience Reviews, 116,57-84.

Draut, A. E., Clift, P. D., Hannigan, R. E., Layne, G. \& Shimizu, N. 2002. A model for continental crust genesis by arc accretion; rare earth element evidence from the Irish Caledonides. Earth \& Planetary Science Letters, 203, 861-877.

Drummond, M. S. \& Defant, M. J. 1990. A model for Trondhjemite- tonalite- dacite genesis and crustal growth via slab melting - Archean to modern compari- sons. Journal of Geophysical Research Solid Earth and Planets, 95, 21 503-21 521.

Ducea, M. \& Saleeby, J. 1998. A case for delamination of the deep batholithic crust beneath the Sierra

Nevada, California.InternationalGeologyReview, 40, 7893. Foley, S. F., Buhre, S. \& Jacob, D. E. 2003. Evolution of the Archaean crust by delamination and shallow subduction. Nature, 421, 249-252.

Gaetani, G. A. \& Grove, T. L. 1998. The influence of water on melting of mantle peridotite. Contributions to Mineralogy and Petrology, 131, 323 -346 .

Gastil, R. G. 1960. The distribution of mineral dates in time and space. American Journal of Science, 258, 1-35.

Gill,J.B.1981.OrogenicAndesitesandPlate Tectonics. Springer, Berlin.

Griffin, W. L., O’Reilly, S. Y., Afonso, J. C. \& Begg, G. C. 2009. The composition and evolution of litho- spheric mantle: a re-evaluation and its tectonic impli- cations. Journal of Petrology, 50, 1185-1204.

Greene, A. R., DeBari, S. M., Kelemen, P. B., Blusztajn, J. \& Clift, P. D. 2006. A detailed geochemical study of island arc crust: the Talkeetna arc section, South-Central Alaska.Journal of Petrology, 47, 1051-

1093. Hacker, B. R., Kelemen, P. B. \& Behn, M. D. 2011. Differentiation of the continental crust by relamina- tion. Earth and Planetary Science Letters, 307, 501-516.

Hamilton, W. B. 2011. Plate tectonics began in Neopro- terozoic time, and plumes from deep mantle have never operated. Lithos, 123, 1-20.

Harrison, T. M. 2009. The Hadean crust: evidence from $.4 \mathrm{Ga}$ Zircons. Annual Review of Earth and Planetary Sciences, 37, 479-505.

Hawkesworth, C. J. \& Kemp, A. I. S. 2006. The differen- tiation and rates of generation of the continental crust. ChemicalGeology,226,134-143.

Hawkesworth, C. J., Cawood, P., Kemp, T., Storey, C. \& Dhuime, B. 2009. A matter of preservation. Science, 323, 49-50.

Hawkesworth, C. J., Dhuime, B., Pietranik, A. B., Cawood, P. A., Kemp, A. I. S. \& Storey, C. D. 2010. The generation and evolution of the continental crust. Journal of the Geological Society, $167,229-248$. 
Hiess, J., Yi, K., Woodhead, J., Ireland, T. \& Rattenbury, M. 2014. Gondwana margin evolution from zircon REE, $\mathrm{O}$ and $\mathrm{Hf}$ signatures of Western Province gneisses, Zealandia. In: Roberts, N. M. W., Van Kra- nendonk, M., Parman, S., Shirey, S. \& Clift, P. D. (eds) Continent Formation Through Time. Geological Society, London, Special Publications, 389, First pub- lished online June 2, 2014, http://dx.doi.org/10.1144/ SP389.10

Hofmann, A. W. 1988. Chemical differentiation of the earth - the relationship between mantle, continental- crust, and oceanic-crust. Earth And Planetary Science Letters, 90, 297-314.

Jagoutz, O. \& Behn, M. D. 2013. Foundering of lower island-arc crust as an explanation for the origin of the continental MOHO. Nature, 504, 131134.

Jagoutz, O., Mü ntener, O., Burg, J. P., Ulmer, P. \& Jagoutz, E. 2006. Lower continental crust formation through focused flow in $\mathrm{km}$-scale melt conduits: the zoned ultramafic bodies of the Chilas Complex in the Kohistan island arc (NW Pakistan). Earth and Plane- tary Science Letters, 242,320-342.

Kay, R. W. \& Kay, S. M. 1993. Delamination and delamination magmatism. Tectonophysics, 219, 177-189.

Kelemen, P. B. 1995. Genesis of high Mg\# andesites and the continental crust. Contributions to Mineralogy and Petrology, 120, 1-19.

Kelemen, P. B., Hart, S. R. \& Bernstein, S. 1998. Silica enrichment in the continental upper mantle via melt/ rock reaction. Earth and Planetary Science Letters, 164, 387-406.

Kemp, A. I. S., Hawkesworth, C. J., Paterson, B. A. \& Kinny, P. D. 2006. Episodic growth of the Gondwana supercontinent from hafnium and oxygen isotopes in zircon. Nature, 439, 580-583.

Kemp, A. I. S., Wilde, S. A. et al. 2010. Hadean crustal evolution revisited: new constraints from $\mathrm{Pb}-\mathrm{Hf}$ isotope systematics of the Jack Hills zircons. Earth and Planetary Science Letters, 296, 45-56.

Kerr, A. C., White, R. V. \& Saunders, A. D. 2000. LIP reading: recognizing oceanic plateaux in the geological record. Journal of Petrology, 41, 1041 1056.

Kleinhanns, I. C., Fullgraf, T., Wilsky, F., Nolte, N., Fliegel, D., Klemd, R. \& Hansen, B. T. 2013. U- Pb zircon ages and (isotope) geochemical signatures of the Kamanjab Inlier (NW Namibia): constraints on Palaeoproterozoic crustal evolution along the southern Congo craton. In: Roberts, N. M. W., Van Kranendonk, M., Parman, S., Shirey, S. \& Clift, P. D. (eds) Continent Formation Through Time. Geological Society, London, Special Publications, 389, First published online August 22, 2013, http://dx. doi.org/10.1144/SP389.1

Kodaira, S., Sato, T., Takahashi, N., Miura, S., Tamura, Y., Tatsumi, Y. \& Kaneda, Y. 2007. New seismological constraints on growth of continental crust in the Izu-Bonin intra-oceanic arc. Geology, 35, 1031-1034.

Kushiro, I. 1974. Melting of hydrous upper mantle and possible generation of andesitic magma approach from synthetic systems. Earth And Planetary Science Letters, 22, 294-299.

Lancaster, P., Storey, C. D. \& Hawkesworth, C. J. 2014. The Eoarchaean foundation of the North
Atlantic Craton. In: Roberts, N. M. W., Van Kranen- donk, M., Parman, S., Shirey, S. \& Clift, P. D. (eds) Continent Formation Through Time. Geological Society, London, Special Publications, 389, First pub- lished online August 18, 2014, http://dx.doi.org/10. 1144/SP389.11

Leat, P. T. \& Larter, R. D. 2003. Intra-oceanic subduc- tion systems: introduction. In: Leat, P. T. \& Larter,

R. D. (eds) Intra-Oceanic Subdcution Systems: Tectonic and Magmatic Processes. Geological Society, London, Special Publications, 219, 1-17.

Lee, C.-T. A., Mortin, D. M., Kistler, R. W. \& Baird, A. K. 2007. Petrology and tectonics of Phanerozoic continent formation: from island arcs to accretion and continental arc magmatism. Earth \& Planetary Science Letters, 263, 370-387.

Martin, H., Smithies, R. H., Rapp, R., Moyen, J. F. \& Champion, D. 2005. An overview of adakite, tonalite- trondhjemite- granodiorite (TTG), and sanukitoid: relationships and some implications for crustal evolution. Lithos, 79, 1-24.

Moorbath, S., O'Nions, R. K. \& Pankhurst, R. J. 1973. Early Archaean age for Isua Iron Formation, West Greenland. Nature, 245, 138-139.

Moore, W. B. \& Webb, A. A. G. 2013. Heat-pipe Earth. Nature, 501, 501-505.

Moores, E. M. 1993. Neoproterozoic crustal thinning, emergence of continents, and origin of the Phanerozoic ecosystem: a model. Geology, 21, 5-8.

Nebel, O., Rapp, R. P. \& Yaxley, G. M. 2014. The role of detrital zircons in Hadean crustal research. Lithos, 190, 313-327.

Nutman, A. P. 2001. On the scarcity of .3900 Ma detrital zircons in $\geq 3500 \mathrm{Ma}$ metasediments. Precambrian Research,105,93-114.

Nutman, A. P., McGregor, V. R., Friend, C. R. L., Bennett, V. C. \& Kinny, P. D. 1996. The Itsaq Gneiss Complex of southern west Greenland; the world's most extensive record of early crustal evolution (3900-3600 Ma). Precambrian Research, 78, 1-39.

Nutman, A. P., Friend, C. R. L. \& Bennett, V. C. 2002. Evidence for 3650 - $3600 \mathrm{Ma}$ assembly of the northern end of the Itsaq Gneiss Complex, Greenland: impli- cation for early Archaean tectonics. Tectonics, 21, 5.1-5.28.

Nutman, A. P., Friend, C. R. L., Horie, K. \& Hidaka, H. 2007. The Itsaq gneiss complex of southern West Greenland and the construction of Eoarchean crust at convergent plate boundaries. In: Van Kranendonk

M. J., Smithies, R. H. \& Bennett, V. (eds) Earth's Oldest Rocks. Elsevier, Developments in Precambrian Geology, Amsterdam, 15, 187-218.

Nutman, A. P., Bennett, V. C. \& Friend, C. R. L. 2013. The emergence of the Eoarchaean proto-arc: evolution of a c. $3700 \mathrm{Ma}$ convergent plate boundary at Isua, southern West Greenland. In: Roberts, N. M. W., Van Kranendonk, M., Parman, S., Shirey, S. \& Clift, P. D. (eds) Continent Formation Through Time. Geological Society, London, Special Publi- cations, 389, First published online September 9, 2013, http://dx.doi.org/10.1144/SP389.5

O'Neill, C., Lenardic, A., Moresi, L., Torsvik, T. H. \& Lee, C. T. 2007. Episodic precambrian subduction. Earth and Planetary Science Letters, 262,552-562. 
O’Neill, C., Lenardic, A. \& Condie, K. C. 2013. Earth's punctuated tectonic evolution: cause and effect. In: Roberts, N. M. W., Van Kranendonk, M., Parman, S., Shirey, S. \& Clift, P. D. (eds) Continent Formation Through Time. Geologica Society, London, Special Publications, 389, First published online November 6, 2013, http://dx.doi.org/10. 1144/SP389.4

Parman, S. W. 2007. Helium isotopic evidence for episo- dic mantle melting and crustal growth Nature, 446, 900-903.

Parman, S. W. \& Grove, T. L. 2004. Harzburgite melting with and without $\mathrm{H}_{2} \mathrm{O}$ : experimental data and predic- tive modeling. Journal of Geophysical Research-Solid Earth, 109.

Pearce, J. A., Stern, R. J., Bloomer, S. H. \& Fryer, P. 2005. Geochemical mapping of the Mariana arcbasin system: implications for the nature and distribution of subduction components. Geochemistry Geophysics Geosystems, 6 Q07006, http://dx.doi.org/10.1029/ 2004GC000895

Percival, J. A. 2007. Eo- to Mesoarchean terranes of the Superior Province and their tectonic context. In: Van Kranendonk, M. J., Smithies, R. H. \& Bennett,

V. (eds) Earth's Oldest Rocks: Developments in Precambrian Geology. Elsevier, Amsterdam, 15, 1065-1085.

Petterson, M. G. \& Treloar, P. J. 2004. Volcanostrati- graphy of arc volcanic sequences in the Kohistan arc, North Pakistan: volcanism within island arc, back- arc-basin, and intracontinental tectonic settings. Journal of Volcanology and Geothermal Research, 130, 147178.

Petersson, A., Scherstén, A., Andersson,J. \&Mö

Iler,

C. 2013. Zircon $\mathrm{U}-\mathrm{Pb}$ and $\mathrm{Hf}-$ isotopes from the eastern part of the Sveconorwegian Orogen, SW Sweden: implications for the growth of Fennoscandia. In: Roberts, N. M. W., Van Kranendonk, M., Parman, S., Shirey, S. \& Clift, P. D. (eds) Continent Formation Through Time. Geological Society, London, Special Publications, 389, First published online August 22, 2013, http://dx.doi.org/10.1144/SP389.2

Piper, J. D. 2013a. A planetary perspective on Earth evol- ution: lid tectonics before plate tectonics. Tectonophy- sics, 589, 44-56.

Piper, J. D. A. 2013b. Supercontinent integrity between

0.8 and $0.6 \mathrm{Ga}$ : the nemesis of Rodinia? In: Roberts,

N. M. W., Van Kranendonk, M., Parman, S., Shirey, S. \& Clift, P. D. (eds) Continent Formation Through Time. Geological Society, London, Special Publications, 389, First published online October 28 http://dx.doi.org/10.1144/SP389.8

Polat, A., Kerrich, R. \& Wyman, D. A. 1998. The late Archean Schreiber-Hemlo and White River-Dayohessarah greenstone belts, Superior Province: collages of oceanic plateaus and subductionaccretion com- plexes. Tectonophysics, 289, 295 326.

Polat, A., Hofmann, A. W. \& Rosing, M. T. 2002 Boninite-like volcanic rocks in the $3.7-3.8 \mathrm{Ga}$ Isua greenstone belt, West Greenland: geochemical evi- dence for intra-oceanic subduction zone processes in the early Earth. Chemical Geology, 184 231-254

Rapp, R. P.\& Watson, E. B. 1995. Dehydration melting of metabasalt at $8-32 \mathrm{kbar}$ - implications for continental growth and crust-mantle recycling. Journal of Petrology, 36, 891-931.

Reimink, J. R., Chacko, T., Stern, R. A. \& Heaman, L. M. 2014. Earth's earliest evolved crust generated in and Iceland-like setting. Nature Geoscience, 7, $529 \quad-\quad 533$. http://dx.doi.org/10.1038/NGEO2170

Rino, S., Komiya, T., Windley, B. F., Katayama, I., Motoki, A. \& Hirata, T. 2004. Major episodic increases of continental crustal growth determined from zircon ages of river sands; implications for mantle overturns in the Early Precambrian. Physics of the Earth and Planetary Interiors, 146, 369-394.

Roberts, N. M. 2013. The boring billion? - Lid tectonics, continental growth and environmental change associated with the Columbia supercontinent. Geo- science Frontiers, 4, 681-691.

Roberts, N. M. W. 2012. Increased loss of continental crust during supercontinent amalgamation. Gondwana Research,21,994-1000.

Roberts, N. M. W. \& Spencer, C. J. 2014. The zircon archive of continent formation through time. In: Roberts, N. M. W., Van Kranendonk, M., Parman, S., Shirey, S. \& Clift, P. D. (eds) Conti- nent Formation Through Time. Geological Society, London, Special Publications, 389, First published online November 7, 2014 http://dx.doi.org/10.1144/ SP389.14

Rudnick, R. L. 1995. Making continental crust. Nature, 378, 571-577.

Rudnick, R. L. \& Fountain, D. M. 1995. Nature and composition of the continental crust: a lower crustal perspective. Reviews of Geophysics, 33, 267-309.

Rudnick, R. L. \& Gao, S. 2003. Composition of the continental crust. Treatise in Geochemistry, 3, 1-64.

Santosh, M., Maruyama, S. \& Yamamoto, S. 2009. The making and breaking of supercontinents: some speculations based on superplumes, super downwel- ling and the role of tectosphere. Gondwana Research, 15, 324-341.

Scholl, D. W. \& von Huene, R. 2007. Crustal recycling at modern subduction zones applied to the past issues of growth and preservation of continental basement crust, mantle geochemistry, and supercontinent recon- struction. In: Hatcher, J. R. D., Carlson, M. P., McBride, J. H. \& Catalán, J. R. M. (eds) 4-D Frame-work of Continental Crust. Geological Society of America, Boulder, CO, Memoirs, 200, 9-32.

Scholl, D. W. \& von Huene, R. 2009. Implications of estimated magmatic additions and recycling losses at the subduction zones of accretionary (non-collisional) and collisional (suturing) orogens. In: Cawood, P. \& Krö ner, A. (eds) Accretionary Orogens in Space and Time. Geological Society, London, Special Publi- cations, 318, 105-125.

Shirey, S. B. \& Richardson, S. H. 2011. Start of the Wilson cycle at $3 \mathrm{Ga}$ shown by diamonds from sub- continental mantle. Science, 333, $434-$ 436

Sizova, E., Gerya, T. \& Brown, M. 2014. Contrasting styles of Phanerozoic and Precambrian continental collision. Gondwana Research, 25, 522-545.

Smith, E. M., Kopylova, M. G., Nowell, G. M., Pearson, D. G. \& Ryder, J. 2012. Archean mantle fluids preservded in fibrous diamonds from Wawa, Superior craton. Geology, 40, 1071 1074. 
Smithies, R. H. 2000. The Archaean tonalite- trondhjemite-granodiorite (TTG) series is not an analogue of Cenozoic adakites. Earth and Planetary Science Letters, 182, 115-125.

Smithies, R. H., Champion, D. C., Van Kranendonk, M. J., Howard, H. M. \& Hickman, A. H. 2005. Modern-style subduction processes in the Mesoarch- aean: geochemical evidence from the 3.12 Ga Whundo intra-oceanic arc. Earth and PlanetaryScience Letters, 231, 221-237.

Smithies, R. H., Van Kranendonk, M. J. \& Champion, D. C. 2007. The Mesoarchaean emergence of modern style subduction. Gondwana Research, 11, 50-68.

Smithies, R. H., Champion, D. C. \& Van Kranendonk, M. J. 2009. Formation of Paleoarchean continental crust through infracrustal melting of enriched basalt. Earth and Planetary Science Letters, 281, 298 $-306$.

Spencer, C. J., Hawkesworth, C., Cawood, P. A. \& Dhuime, B. 2013. Not all supercontinents are created equal: Gondwana-Rodinia case study. Geology, 41, 795-798.

Stein, M. \& Hofmann, A. W. 1994. Mantle plumes and episodic crustal growth. Nature, 372, 63-68.

Stern, R. J. 2005. Evidence from ophiolites, blueschists, and ultrahigh-pressure metamorphic terranes that the modern episode of subduction tectonics began in Neo- proterozoic time. Geology, 33, 557-560.

Stern, R. J. 2008. Modern-style plate tectonics began in Neoproterozoic time: an alternative interpreta- tion of Earth's tectonic history. Geological Society of America Special Papers, 440, 265-280.

Stern, C. R. 2011. Subduction erosion: rates, mechan- isms, and its role in arc magmatism and the evolu- tion of the continental crust and mantle. Gondwana Research,20,284-308.

Stern, R. J. \& Scholl, D. W. 2010. Yin and yang of continental crust creation and destruction by plate tec- tonic processes. International Geology Review, 52, 1-31.

Sun, S. S. \& McDonough, W. F. 1989. Chemical and isotopic systematic of oceanic basalts: implications for mantle composition and processes. In: Saunders,

A. D. \& Norry, M. J. (eds) Magmatism in the Ocean Basins. Geological Society, London, Special Publi- cations, 42, 313-345.

Takahashi, N., Kodaira, S., Klemperer, S. L., Tatsumi, Y., Kaneda, Y. S. \& Suyehiro, K. 2007. Crustal structure and evolution of the Mariana intraoceanic island arc. Geology, 35, 203-206.

Tatsumi, Y., Shukuno, H., Tani, K., Takahashi, N., Kodaira, S. \& Kogiso, T. 2008. Structure and growth of the Izu-Bonin-Mariana arc crust: 2 . Role of crust- mantle transformation and the transparent $\mathrm{MOHO}$ in arc crust evolution. Journal of Geophysical Research, 113, B02203, http://dx.doi.org/10.1029/2007JB005121

Taylor, S. R. 1967. The origin and growth of continents. Tectonophysics, 4, 17-34.

Taylor, S. R. \& McLennan, S. M. 1985. The Continental Crust: Its Composition and Evolution. Blackwell Scientific, Oxford, 1-312.

Teng, L. S. 1990. Geotectonic evolution of late Cenozoic arc-continent collision in Taiwan. Tectonophysics, 183, 57-76.
Tessalina, S. G., Bourdon, B., Van Kranendonk, M., Birck, J.-L. \& Philippot, P. 2010. Influence of Hadean crust evident in basalts and cherts from the Pilbara Craton. Nature Geoscience, 3, 214-217.

Turcotte, D. L. 1993. An episodic hypothesis for Venu- sian tectonics. Journal of Geophysical Research: Planets, 98, 17061-17068.

Valley, J. W., Lackey, J. S. et al. 2005. 4.4 billion years of crustal maturation: oxygen isotope ratios of mag- matic zircon. Contributions to Mineralogy and Petrol- ogy, 150, 561-580.

Valley, J. W., Cavosie, A. J. et al. 2014. Hadean age for a post-magma-ocean zircon confirmed by atomprobe tomography. Nature Geoscience, 7, 219-223. Van Kranendonk, M. J. 2010. Two types of Archean con- tinental crust: plume and 1286 plate tectonics on early Earth. American Journal of Science, 310, 11871209. Van Kranendonk, M. J. 2011. Onset of plate

Science, 333, 413-414.

Van Kranendonk, M. J. \& Kirkland, C. L. 2013. Orogenic climax of Earth: the $1.2-1.1 \mathrm{Ga}$ Grenvillian Superevent. Geology, 41,735-738.

Van Kranendonk, M. J., Hickman, A.\& Smithies, R. H. 2007a. The East Pilbara Terrane of the Pilbara Craton, Western Australia: formation of a continental nucleus through repeated mantle plume magmatism. In: Van Kranendonk, M. J., Smithies, R. H. \& Bennet, V. (eds) Earth's Oldest Rocks. Elsevier, Amsterdam, Developments in Precambrian Geology, 15, 307-337. Van Kranendonk, M. J., Smithies, R. H., Hickman, A. H. \& Champion, D. C. 2007b. Review: secular tec- tonic evolution of Archean continental crust: interplay between horizontal and vertical processes in the for- mation of the Pilbara Craton, Australia. Terra Nova, 19, 1-38.

Van Kranendonk, M. J., Smithies, R. H. et al. 2014. Making it thick: a volcanic plateau origin of Paleoarch- ean continental lithosphere of the Pilbara and Kaapvaal cratons. In: Roberts, N. M. W., Van Kranendonk, M., Parman, S., Shirey, S. \& Clift, P. D. (eds) Con- tinent Formation Through Time. Geological Society, London, Special Publications, 389, First published online September 3, 2014, http://dx.doi.org/10. 1144/SP389.12

Watson, E. B. \& Harrison, T. M. 2005. Zircon ther- mometer reveals minimum melting conditions on ear- liest Earth. Science, 308, 841 844.

White, R. V., Tarney, J., Kerr, A. C., Saunders, A. D., Kempton, P. D., Pringle, M. S. \& Klaver, G. T. 1999. Modification of an oceanic plateau, Aruba, Dutch Caribbean: implications for the generation of continental crust. Lithos, 46, 43-68.

Wilde, S. A., Valley, J. W., Peck, W. H. \& Graham, C. M. 2001. Evidence from detrital zircons for the exist- ence of continental crust and oceans on the Earth 4.4Gyr ago. Nature, 409, 175-178.

Windley, B. F. \& Bridgwater, D. 1971. The Evolution of Archaean Low- and High-grade Terrains. Geological Society of Australia, Special Publications, 3, 33-46.

Zeh, A., Gerdes,A.\& Millonig, L. 2011. Hafniumisotope record of the Ancient Gneiss Complex, Swaziland, southern Africa; evidence for Archaean crust-mantle formation and crust reworking between 3.66 and $2.73 \mathrm{Ga}$. Journal of the Geological Society, 168, 1-11. 